\title{
Enzymatic Breakdown of Cell Wall Polysaccharides of Guava (Psidium Guajava L.) Puree
}

\author{
Odile Marcelin ${ }^{1}$, Abraham B. Smith ${ }^{2}$, Estelle Bonnin ${ }^{3}$ and Jean-Marc Brillouet ${ }^{4}$ \\ ${ }^{I}$ (Université des Antilles, EA929 AIHP GEODE Groupe BIOSPHERES, Campus Universitaire de Schoelcher, \\ 97275 Scholcher Cedex, France) \\ ${ }^{2}$ (Institute of Food Technology, Njala University, Sierra Leone) \\ ${ }^{3}$ (INRA, UR 1268 Biopolymères, Interactions, Assemblages, 44316 NANTES Cedex 3, France) \\ 4(INRA, UR 1083 Sciences pour l'œnologie, 2 place Viala, 34060 Montpellier Cedex 2, France)
}

\begin{abstract}
Due to its high viscosity, guava puree obtained by physical treatment cannot be used as it is for optimum juice production and needs enzymatic treatment to reduce the puree viscosity without pulp/serum separation. In the present study, guava puree was treated with various commercial enzymes in order to identify the best commercial enzyme, Klerzyme Extra. Cell walls were extracted using the sodium deoxycholatephenol/acetic acid/water procedure and then separated into parenchyma cell walls and stone cell walls by physical and enzymatic treatment. Enzyme was applied to suspensions of parenchyma cell walls and to soluble polysaccharides extracted from guava puree. Hydrolysis of parenchyma cell walls was partial while stone cell walls were scarcely affected by enzymes which break down polysaccharides. Serum-soluble polysaccharides were broken down into smaller molecules. Enzymatic hydrolysis of guava puree resembled maceration, and was all the more complete as enzyme incubation time increased. The selected enzyme produced a product capable of being pumped without pulp/serum separation.
\end{abstract}

Keywords: Guava,PsidiumguajavaL., Cell wall polysaccharides, Stone cells, Parenchyma cells, Klerzyme Extra

\section{Introduction}

Guava (Psidiumguajava L.), widely known for its nutritional benefits worldwide, is cultivated in regions stretching from the west coast of Africa to the Pacific region and has spread widely throughout the tropics. The fruit is mostly consumed fresh but is also processed into juice, nectar, puree, jam or jelly for its pleasant taste and nutritional benefits. These processed products are produced from a fine guava puree obtained by crushing the fruit and sieving the coarse puree. The fine guava puree has a high viscosity. Consequently, trials have been performed in the past to reduce the viscosity of guava puree using enzyme preparations [1]. Enzyme preparations have been used for over 40 years in fruit juice production as processing aids. Nowadays, enzyme preparations are a prerequisite for the production of clear and stable juices and high-quality concentrates, for increasing juice yields, and for achieving good process economy [2]. Up until now, enzyme treatments of guava puree were performed rather empirically and their effects on the cell walls and the polysaccharides present in the soluble fraction have not been elucidated [3]. [4] showed a high decrease in water-soluble, oxalate-soluble and alkali-soluble pectic fractions when the fruit was subjected to pectinolytic treatment.

Guava fruit is formed of two main parts, which are the thin epicarp (outer envelope of the fruit), and the pericarp which is composed of the mesocarp and the endocarp containing the seeds and the central core. Work previously carried out by our team has shown that guava pericarp contains heterogeneous tissues consisting of two main cell types: parenchyma cells and stone cells [5]. Stone cells are surrounded by very thick secondary walls and they are responsible for the grainy mouthfeel when the fresh fruit or products derived from them are consumed [4]. The predominant structural cell wall compounds in stone cells are mainly cellulose, acetylated xylans and lignin [5]. On the other hand, the parenchyma cells are surrounded by thin, non-lignified primary walls made up of 55-60\% neutral polysaccharides (mainly cellulose, xyloglucan, xylan, arabinan and arabinogalactans of types I and II) linked to weakly methyl-esterified galacturonans. From their structure, stone cells would appear to be resistant to glycosyl hydrolases whereas the parenchyma cells would appear to constitute a fraction accessible to glycosyl hydrolases. Water-soluble pectins of guava tissues have typical rhamnogalacturonan structures linked to arabinans and type II arabinogalactans with degrees of methylation of $64.2 \%$ and $68.1 \%$ for water-soluble pectins of the endocarp and mesocarp, respectively [6,7].

The aim of the present study is to bring about a reduction in the consistency of fine guava puree without causing pulp/serum separation. This may be achieved by an understanding of how enzymatic breakdown of polysaccharides from cell walls and serum occurs when fine guava puree is treated with an enzyme preparation. 
Industrial processing of guava normally provides crushed fruits which are sieved on a $2 \mathrm{~mm}$ screen, followed after enzyme treatment by a 0.4 or $0.5 \mathrm{~mm}$ screen. The resulting puree is used in a variety of food applications in the food industry. Up until now, work on enzyme treatment of guava puree has not investigated the soluble and cell wall polysaccharides and the specificity of the enzymes. The present study therefore fills a gap and represents an important contribution to this field.

\subsection{Fruit and preparation of crude puree}

\section{Materials And Methods}

White guava (family Myrtaceae; cvSuprême) free of any visible defects was harvested at the mature/ripe transition stage ("turning" stage) from a fruit orchard of Nyombé, Cameroon. Guava fruit was cut into pieces on a laboratory scale, gently homogenized for $1 \mathrm{~min}$ in a blender and then extensively sieved on a 2 $\mathrm{mm}$ screen. This stage resulted in the removal of seeds and skin fragments. Sodium azide was added $(0.2 \mathrm{~g} / \mathrm{kg})$. The puree obtained at this stage was termed crude puree and it was stored in polyethylene freezer bags at $-20^{\circ} \mathrm{C}$ until use. The enzyme treatments were performed on the crude puree after thawing. Enzyme-treated crude puree was sieved on a $0.5 \mathrm{~mm}$ screen, and the sieved puree thus obtained represented the starting material for further investigations.

\subsection{Enzyme mixtures and assays}

Four commercial enzyme preparations with varying pectinolytic, hemicellulolytic and cellulolytic activities were tested on crude guava puree with the technological aim of producing a free-flowing puree without pulp/serum separation. They were RapidasePress, Klerzyme 40, Klerzyme Extra (Aspergillus niger) (Gist Brocades S.A., France) and Pectinex Ultra SPL (Trichoderma viride) (Novo-Nordisk Ferment AG, Switzerland). For powdered preparations (Klerzyme 40, Klerzyme Extra),stock solutions were prepared at 50 $\mathrm{mg} / \mathrm{ml}$ and used for the determination of protein content and enzyme activity.

Protein content was assayed according to the Lowry method [8] after precipitation with trichloroacetic acid (TCA) (7.5\% final concentration) and resuspension of the pellet in $0.1 \mathrm{M}$ sodium hydroxide $(\mathrm{NaOH})$. The assays were carried out in duplicate.

Glycoside hydrolase activity was assayed by adding $600 \mu \mathrm{L}$ of polysaccharide dissolved in $0.1 \mathrm{M}$ acetate buffer ( $\mathrm{pH} 4.2$ ) to $600 \mu \mathrm{L}$ of enzyme solution at $40^{\circ} \mathrm{C}$ with stirring for 20 min. Liberated reducing sugars were assayed according to [9]. Pectin methylesterase was assayed at $30^{\circ} \mathrm{C}$ by incubating $25 \mathrm{~mL}$ of $0.5 \%$ apple pectin in $0.1 \mathrm{M}$ sodium chloride $(\mathrm{NaCl})$ adjusted to $\mathrm{pH} 4.5$ with $1 \mathrm{M} \mathrm{NaOH}$ and adding $1 \mathrm{~mL}$ of enzyme solution [10]. Released carboxyl groups were assayed by automated titration with $20.5 \mathrm{mM}$ potassium hydroxide (KOH). Pectin lyase was assayed by incubating $500 \mu \mathrm{l}$ of $1 \%$ citrus pectin in McIlvaine buffer (pH 6) with $100 \mu \mathrm{l}$ of enzyme solution for $20 \mathrm{~min}$ at $25^{\circ} \mathrm{C}$. After dilution, the absorbance was measured at $235 \mathrm{~nm}$ [11].

Glycosidase activity was assayed by incubating $100 \mu \mathrm{l}$ of $4 \mathrm{mMp}$-nitrophenyl glycoside in $0.1 \mathrm{M}$ acetate buffer ( $\mathrm{pH} 4.2$ ) with $100 \mu \mathrm{l}$ of enzyme solution at $40^{\circ} \mathrm{C}$ for $20 \mathrm{~min}$. Liberated $p$-nitrophenol was assayed after the addition of $600 \mu \mathrm{l}$ of $1 \mathrm{M}$ sodium carbonate by measuring the absorbance at $400 \mathrm{~nm}$ [12].

A unit of 1 nkat represents the amount of enzyme liberating $1 \mathrm{nmol}$ of reaction products per second, under the $\mathrm{pH}$ and temperature conditions described above.

\subsection{Selection of the appropriate enzyme}

Crude puree $(60 \mathrm{~g})$ was preincubated at $30^{\circ} \mathrm{C}$ for $20 \mathrm{~min}$, with stirring (blade propeller), and then subjected to enzyme treatment with either RapidasePress, Klerzyme 40, Klerzyme Extra or Pectinex Ultra SPL using $600 \mu \mathrm{g} / \mathrm{ml}$ of enzyme preparation, except for Klerzyme 40. The incubation was stopped after $24 \mathrm{~h}$ and water was added to compensate for evaporation. After enzymatic treatment, crude puree was sieved on a $0.5 \mathrm{~mm}$ screen. The sieved puree and the sieve residue were recovered separately. Pulp/serum separation was evaluated by allowing aliquots of the various sieved purees to stand in a $10 \mathrm{~mL}$ graduated cylinder for $24 \mathrm{~h}$. The serum was separated from aliquots of sieved puree by centrifugation $\left(10,000 \mathrm{~g}, 15 \mathrm{~min}, 4^{\circ} \mathrm{C}\right)$ and the viscosity was determined at $25^{\circ} \mathrm{C}$ with an Automated Schott Gerate AVS 400 viscometer (flow time of the aqueous solvent $85.02 \mathrm{~s})$.

\subsection{Treatment of crude puree with Klerzyme Extra}

Crude puree $(60 \mathrm{~g})$ was preincubated at $40^{\circ} \mathrm{C}$ for $20 \mathrm{~min}$, with gentle stirring using a blade propeller, and then subjected to enzyme treatment using $120 \mu \mathrm{g} / \mathrm{ml}$ of enzyme. The incubation was stopped after $0 \mathrm{~h}, 0.5 \mathrm{~h}$, $2 \mathrm{~h}, 5 \mathrm{~h}$ and $19 \mathrm{~h}$. After enzyme treatment, the treated puree was sieved on a $0.5 \mathrm{~mm}$ screen. The sieved puree and the sieve residue were recovered separately and the cell walls were extracted. The serum-soluble polysaccharides were obtained from an aliquot of sieved puree as described below. 


\subsection{Preparation of total cell wall material (CWM)}

Cell wall material was prepared by the method described by [13] with modifications.Sieved puree and sieve residue from Klerzyme Extra treatment were suspended in cold $1 \%$ sodium deoxycholate (SDC) containing $6 \mathrm{mM}$ sodiummetabisulfite $\left(2: 1 \mathrm{w} / \mathrm{w}\right.$ liquid/solid ratio), and the slurry was stirred for $16 \mathrm{~h}$ at $4{ }^{\circ} \mathrm{C}$. After centrifugation for $10 \mathrm{~min}$ at $5000 \mathrm{~g}$, the pellet was washed three times with $6 \mathrm{mM}$ sodium metabisulfite buffer, followed each time by centrifugation. Wet residue was extracted three times with a 2:1:1 phenol-acetic acid-water (PAW) mixture, centrifuged and then washed once with $6 \mathrm{mM}$ sodium metabisulfite and twice with water to obtain cell wall material. CWM was then dried in glass crucibles by solvent exchange using ethanol, acetone and ether, and stored for $24 \mathrm{~h}$ in a vacuum oven $\left(50^{\circ} \mathrm{C}\right)$ over phosphorus pentoxide $\left(\mathrm{P}_{2} \mathrm{O}_{5}\right)$. The CWM obtained was used as starting material for the preparation of stone cell wall and parenchyma cell wall.

\subsection{Preparation of stone cell wall and parenchyma cell wall from CWM}

Stone cell wall and parenchyma cell wall were prepared by the method described by [5]. Stone cell wall (SCW) was quantitatively obtained from CWM as follows: CWM $(1 \mathrm{~g})$ was suspended in $0.1 \mathrm{M}$ acetate buffer (200 mL, pH 4.2), and Pectinex Ultra SPL (1.85 mL; Novo-Nordisk Ferment AG, Switzerland) was added. After $48 \mathrm{~h}$ at $30^{\circ} \mathrm{C}$ with stirring, the sample was centrifuged at decreasing speeds from 2000 to $25 \mathrm{~g}$ for varying times of 1 to $5 \mathrm{~min}$. The top layer of residual parenchyma cell wall ghosts was carefully removed with a Pasteur pipette, taking care to avoid the removal of the bottom layer of dense stone cell wall. The purity of stone cell wall was checked under a light microscope by the absence of Congo Red-stainable parenchyma cell wall. The pellet was then thoroughly washed with distilled water and dried by solvent exchange to give stone cell wall from sieved puree $\left(\mathrm{SCW}_{\text {sieved puree }}\right)$ and stone cell wall from sieve residue $\left(\mathrm{SCW}_{\text {sieve residue }}\right)$.

Parenchyma cell wall (PCW) was separated from stone cell wall as follows: CWM (0.2 g) was suspended in aqueous $6 \mathrm{mM}$ sodium metabisulfite $(50 \mathrm{~mL})$ and treated in a Potter-Elvehjem tissue grinder (Wheaton, USA) in order to separate parenchyma cell wall and stone cell wall. Parenchyma cell wall was recovered in the top aqueous phase while stone cell wall settled at the bottom. The partially purified parenchyma cell wall still containing small amounts of stone cell wall was then centrifuged at $1500 \mathrm{~g}$, and the top layer of PCW was carefully recovered. The above operations were repeated until the PCW was completely free from stone cells as checked under a light microscope by the absence of phloroglucinol/ $\mathrm{HCl}$ stainable elements. The $\mathrm{PCW}$ was washed and dried by solvent exchange. Parenchyma cell wall from sieved puree $\left(\mathrm{PCW}_{\text {sieved puree }}\right)$ and parenchyma cell wall from sieve residue $\left(\mathrm{PCW}_{\text {sieve residue }}\right)$ were thus obtained.

\subsection{Preparation of soluble polysaccharides (SP)}

Puree sample was centrifuged at $1000 \mathrm{~g}$ for $15 \mathrm{~min}$ at $4^{\circ} \mathrm{C}$ and the supernatant was recovered. Protein was precipitated with $10 \% \mathrm{TCA}\left(2.5 \mathrm{~g} / \mathrm{g}\right.$ serum, $\left.4^{\circ} \mathrm{C}\right)$, and after centrifugation $\left(9000 \mathrm{~g}, 15 \mathrm{~min}, 4^{\circ} \mathrm{C}\right)$, the supernatant was neutralized with $5 \mathrm{M} \mathrm{KOH}$, dialyzed against distilled water, concentrated under vacuum and freeze-dried. The freeze-dried product thus obtained was used as starting material for the enzymatic breakdown of soluble polysaccharide.

\subsection{Enzymatic breakdown of soluble polysaccharides}

Freeze-dried soluble polysaccharide $(20 \mathrm{mg})$ was dissolved in $0.1 \mathrm{M}$ acetate buffer $(4 \mathrm{ml}, \mathrm{pH} 4)$ and allowed to stand for $20 \mathrm{~min}$ at $40^{\circ} \mathrm{C}$. The enzyme mixture consisting of $1 \mathrm{ml} \mathrm{Klerzyme} \mathrm{Extra/soluble}$ polysaccharide $0.2 \mathrm{~g} / \mathrm{kg}$ diluted in acetate buffer was then added and the mixture was incubated at $40^{\circ} \mathrm{C}$. Aliquots of $1 \mathrm{ml}$ were collected at $0 \mathrm{~h}, 0.5 \mathrm{~h}, 2 \mathrm{~h}, 5 \mathrm{~h}$ and $19 \mathrm{~h}$, heated for $5 \mathrm{~min}$ on a boiling water bath and analysed by size exclusion chromatography.

\subsection{Enzymatic breakdown of parenchyma cell wall}

Parenchyma cell wall $(20 \mathrm{mg}$ ) was suspended in $0.1 \mathrm{M}$ acetate buffer $(4 \mathrm{ml}, \mathrm{pH} 4)$ with stirring for 45 min at $40^{\circ} \mathrm{C}$. The enzyme mixture consisting of $1 \mathrm{ml} \mathrm{Klerzyme} \mathrm{Extra/PCW} 0.2 \mathrm{~g} / \mathrm{kg}$ diluted in acetate buffer was then added and the slurry was incubated for $2 \mathrm{~h}$ or $19 \mathrm{~h}$ at $40^{\circ} \mathrm{C}$. The sample was filtered on a G4 sintered filter and the filtrate heated on a boiling water bath for $5 \mathrm{~min}$. After concentration under vacuum to $1 \mathrm{ml}$, the filtrate was analysed by size exclusion chromatography.

\subsection{Size exclusion chromatography}

Aliquots $(1 \mathrm{ml})$ of supernatant from enzyme treatment were added to $1 \mathrm{ml}$ of $0.1 \mathrm{M}$ acetate buffer $(\mathrm{pH}$ 4) and applied to a Sephadex G-100 column [100 x $1.6 \mathrm{~cm}$; void volume $\left(\mathrm{V}_{\mathrm{o}}\right) 92 \mathrm{ml}$, total volume $\left(\mathrm{V}_{\mathrm{t}}\right) 22 \mathrm{ml}$ ] equilibrated with the same buffer and eluted at a flow rate of $20 \mathrm{ml} / \mathrm{h}$. Fractions $(4 \mathrm{ml})$ were analysed for the content of uronic acids and neutral sugars by automated analytical procedures as described below. 


\subsection{Analytical procedures}

Moisture content was determined by drying over $\mathrm{P}_{2} \mathrm{O}_{5}$ at $50^{\circ} \mathrm{C}$ for $24 \mathrm{~h}$ under reduced pressure.Prior to analysis, CWM was ultrafinely milled in liquid nitrogen $\left(-196^{\circ} \mathrm{C}\right)$ in a Spex 6700 Freezer/Mill for 3 min (maximum impact frequency) [14]. All data are given on a moisture-free basis.

Neutral monosaccharides in SP, CWM and PCW $(5 \mathrm{mg})$ were analysed by hydrolysis with $2 \mathrm{M}$ TCA for $75 \mathrm{~min}$ at $120^{\circ} \mathrm{C}$ [15]. CWM was subjected to Seaman hydrolysis as described by [16], i.e. $72 \%$ (w/w) sulfuric acid, $3 \mathrm{~h}, 25^{\circ} \mathrm{C}$, and then $1 \mathrm{M}$ sulfuric acid, $2 \mathrm{~h}, 100^{\circ} \mathrm{C}$. After acid hydrolysis, sugars were derivatized into their alditol acetates [17] and analysed by GC at $210^{\circ} \mathrm{C}$ on a DB-225 capillary column $(30 \mathrm{~m} \times 0.32 \mathrm{~mm}$ i.d., $0.25-\mu \mathrm{m}$ film; J\&W Scientific) with hydrogen as the carrier gas.

Soluble polysaccharides were methylated with methyl iodide as described by [18]. After hydrolysis, the partially methylated sugars were converted to alditol acetates and analysed on DB-1 and DB-225 capillary columns. Identification was based on retention times and confirmed by GC-MS, using the DB-225 column (oncolumn injection at $50^{\circ} \mathrm{C}$, injector $50^{\circ} \mathrm{C}$ to $220^{\circ} \mathrm{C}$ at $60^{\circ} \mathrm{C} / \mathrm{min}$, oven $90^{\circ} \mathrm{C}$ to $170^{\circ} \mathrm{C}$ at $10^{\circ} \mathrm{C} / \mathrm{min}$ then $5^{\circ} \mathrm{C} / \mathrm{min}$ to $210^{\circ} \mathrm{C}$; helium as carrier gas at $2 \mathrm{ml} / \mathrm{min}$ ) coupled to a Finningan Mat ITD 400 mass spectrometer.

Uronic acids were analysed by the $m$-phenylphenol method [19] without prior de-esterification using a suspension in concentrated sulfuric acid as PCW. Uronic acids and neutral sugars were also analysed on sizeexclusion chromatography fractions by automated $m$-hydroxydiphenyl [20] and orcinol [21] methods, respectively. The results are expressed as anhydro sugars with, as standards, galacturonic acid and arabinose, respectively.

Methyl groups were analysed after de-esterification by enzymatic oxidation of methanol with alcohol oxidase, followed by colorimetric assay of formaldehyde [22]. Acetyl groups were analysed after deesterification by an enzymatic UV method as described by [5]. Protein was assayed by the Kjeldahl method as described by [23] using the factor $\mathrm{N} \times 6.25$.

\subsection{Selection of the appropriate enzyme}

\section{Results And Discussion}

The main enzyme activities in the commercial preparations tested are quantified in Table 1.They all contain not only pectinolytic activity (pectin lyase, pectin methylesterase, endopolygalacturonase, $\beta$-Dgalactanase), but also hemicellulolytic activity ( $\alpha$-L-arabinosidase, $\beta$-D-xylanase, $\beta$-D-mannanase) and cellulolytic activity ( $\beta$-D-glucosidase, $\beta$-D-cellobiohydrolase, carboxymethylcellulase (CMC), endoglucanase).

Table 1. Enzyme activity and protein content of Rapidase Press, Klerzyme 40, Klerzyme Extra and Pectinex Ultra SPL

\begin{tabular}{|c|c|c|c|c|c|c|c|c|}
\hline & \multicolumn{2}{|c|}{ RapidasePress } & \multicolumn{2}{|c|}{ Klerzyme $40^{\mathrm{a}}$} & \multicolumn{2}{|c|}{ KlerzymeExtra $^{\mathrm{a}}$} & \multicolumn{2}{|c|}{ Pectinex Ultra SPL } \\
\hline & $\begin{array}{l}\text { (nkat } \\
/ \mathrm{mL})\end{array}$ & $\begin{array}{l}\text { (nkat } \\
\text { /mg) }\end{array}$ & $\begin{array}{l}\text { (nkat } \\
\text { /mL) }\end{array}$ & $\begin{array}{l}\text { (nkat } \\
\text { /mg) }\end{array}$ & $\begin{array}{l}\text { (nkat } \\
\text { /mL) }\end{array}$ & $\begin{array}{l}\text { (nkat } \\
\text { /mg) }\end{array}$ & $\begin{array}{l}\text { (nkat } \\
\text { /mL) }\end{array}$ & $\begin{array}{l}\text { (nkat } \\
\text { /mg) }\end{array}$ \\
\hline Protein & \multicolumn{2}{|l|}{$7.48^{\mathrm{b}}$} & \multicolumn{2}{|l|}{0.14} & \multicolumn{2}{|l|}{2.07} & \multicolumn{2}{|l|}{11.27} \\
\hline Pectin lyase & $3000^{\mathrm{c}}$ & $402.1^{\mathrm{d}}$ & 14.8 & 105.7 & 9.1 & 4.4 & 21515.2 & 1909.1 \\
\hline Endopoly-galacturonase & 43801.2 & 5871.5 & 1400.6 & 10004.3 & 1026.3 & 495.8 & 24659.0 & 2188.0 \\
\hline Pectinmethyl- esterase & 30000 & 4021.4 & 3000.0 & 21428.6 & 166.7 & 80.5 & 6000.0 & 532.4 \\
\hline Galactanase & 4333.3 & 580.9 & - & - & 191.0 & 92.3 & 4990.0 & 442.8 \\
\hline Arabinosidase & 953.7 & 127.8 & 42.9 & 306.4 & 53.4 & 25.8 & 555.8 & 49.3 \\
\hline Xylanase & 882.6 & 118.3 & - & - & 136.7 & 66.0 & 333.3 & 29.6 \\
\hline Mannanase & 350.3 & 47.0 & 135.5 & 967.9 & 628.4 & 305.6 & 8392.0 & 744.5 \\
\hline $\mathrm{CMC}$ & 531.8 & 71.3 & - & - & 536.1 & 259.0 & 720.7 & 63.9 \\
\hline Endoglucanase $^{\mathrm{e}}$ (Cellulose Azur) & 177.5 & 23.8 & - & - & 195.0 & 94.2 & 125.0 & 11.1 \\
\hline Cellobio- hydrolase & 7.4 & 1.0 & 0.02 & 0.1 & 1.7 & 0.8 & 9.4 & 0.8 \\
\hline Glucosidase & 86.8 & 11.8 & 2.8 & 20.0 & 62.9 & 30.4 & 171.5 & 15.2 \\
\hline
\end{tabular}

${ }^{\mathrm{a}}$ Solution at $50 \mathrm{mg}$ of powder/ml ; ${ }^{\mathrm{b}} \mathrm{mg} / \mathrm{ml} ;{ }^{\mathrm{c}}$ Activity (nKat/ml enzyme), ${ }^{\mathrm{d}}$ Specific activity (nKat/mg enzyme) ; ${ }^{\mathrm{e}}$ Enzyme unit is arbitrarily defined as the amount of enzyme causing an increase in the optical density of 0.01 in $1 \mathrm{~min}$.

Rapidase Press and Klerzyme 40 had mainly pectinolytic activity, leading to macerating capacity on plant cell wall tissues. They are recommended for improving pressing and fruit juice yields. However, and for Rapidase Press in particular, hemicellulolytic and cellulolytic activities were also detected that may result in cell wall disintegration. Pectinex Ultra SPL is commonly used in the fruit juice industry to increase juice yield and reduce pulp viscosity. It showed a broad activity spectrum, but with a predominant pectinolytic activity.

The serum falling numbers (19-20 s) were equivalent for puree incubated with Klerzyme 40, Rapidase Press and Pectinex Ultra SPL. This is consistent with a sharp drop in puree viscosity (liquid consistency). However, Klerzyme 40 and Pectinex Ultra SPL led to pulp/serum separation, resulting in a clarification process in which it is thought that the semi-stable emulsion of colloidal carbohydrates that maintain the insoluble cloudy 
material in suspension is broken [2]. This indicates an excessive breakdown of pectic fractions but also action on cell wall hemicellulosic polymers, causing a high degree of tissue breakdown. The commercial enzyme preparations exhibited mainly pectinolytic activity (especially Klerzyme 40). However, the hemicellulolytic and cellulolytic activities detected were significant in the enzymatic process and led to a disintegrating and/or liquefying action, as suggested by [24].

Only Klerzyme Extra, with the highest serum falling number (26 s), improved the puree flow without causing phase separation.Klerzyme Extra contained pectinolytic, hemicellulolytic and cellulolytic activities. Pectin lyase and endopolygalacturonase activities were of the same order of magnitude as in Klerzyme 40, while the pectin methylesterase activity was much lower. Moreover, this preparation is characterized by a high endoglucanase activity compared to Klerzyme 40. Although Klerzyme Extra contained both pectinolytic and cellulolytic activities, which are expected to confer liquefying properties on it, a maceration action was instead observed on guava puree. This unique mode of action was likely related to the particular structure of guava cell wall. It was therefore of interest to elucidate this unique mode of action. Accordingly, Klerzyme Extra was selected for further investigation which included monitoring the variation in insoluble and soluble cell wall polysaccharides with varying amounts of enzyme and varying incubation times.

\subsection{Hydrolysis of puree}

Table 2 presents the percentage of stone cell wall and parenchyma cell wall of crude guava puree following hydrolysis by Klerzyme Extra for varying incubation times, and sieving on a $0.5 \mathrm{~mm}$ screen. We observed substantial browning of the guava puree during incubation at $40^{\circ} \mathrm{C}$, probably due to oxidation of native tannins as suggested by [25]. The proportion of PCW present in the crude puree gradually decreased from 16 to $11 \mathrm{~g} / \mathrm{kg}$ as the incubation time increased. On the other hand, there was an increase in the proportion of SCW. This enrichment with SCW (34- $42 \mathrm{~g} / \mathrm{kg}$ ) could be linked to the loss of PCW and shows the resistance of SCW to enzyme action. The SCW fraction may not be freely accessible to Klerzyme Extra possibly due to a highly lignified structure [5]. The hydrolysis of the parenchyma cell wall is partial; it reached only about $30 \%$ after $5 \mathrm{~h}$ of incubation, and by extrapolation reached a plateau not exceeding $35 \%$ at the final stage. This result may explain why the products obtained after the enzyme treatment retained a puree consistency regardless of the incubation time.

Table 2. Content $(\mathrm{g} / \mathrm{kg})$ of PCW and SCW in crude puree during enzymatic hydrolysis by Klerzyme Extra

\begin{tabular}{|l|l|l|}
\hline & \multicolumn{2}{|l|}{ Percentage relative to Crude Puree } \\
\hline Incubation time (h) & Parenchyma Cell Wall & Stone Cell Wall \\
\hline 0 & 16 & 35 \\
\hline 0.5 & 14 & 34 \\
\hline 2 & 12 & 36 \\
\hline 5 & 11 & 42 \\
\hline
\end{tabular}

\subsection{Hydrolysis of the parenchyma cell wall}

Table 3 shows the composition of PCW and the percentage hydrolysis of its constituents. The uronic acid, rhamnose, arabinose and methanol content decreased as the incubation time increased. This indicates both hydrolysis and solubilisation of the neutral pectic polymers (arabinans) and acidic pectic polymers (homo- and rhamnogalacturonans). The percentage hydrolysis of these compounds almost reached a maximum value after $19 \mathrm{~h}$ of enzyme treatment. It varied between 77.7 and $91.1 \%$. The fucose, xylose, mannose, galactose, and cellulosic and non-cellulosic glucose content varied in two stages. At the first stage, the content reached a maximum value, which depended on the enzyme incubation time and the compound assayed. At the second stage, the content decreased slightly over time. This could be explained by a faster solubilisation of the pectic polymers which are probably more accessible to Klerzyme Extra. Consequently, the parenchyma cell wall transiently became rich in hydrolysed cellulose and hemicellulose. Only about $30 \%$ of the acetic acid was removed. This substituent was probably linked to the galacturonic acid of the solubilized homo- and rhamnogalacturonans. Galacturonic acid esterified by acetic acid was reported by [26] in the hairy regions of apple juice pectins. The residual acetic acid (about 70\%) could not be totally linked to the uronic acids because only about $20 \%$ remained in the cell wall after $19 \mathrm{~h}$ of enzyme treatment. The hemicellulosic sugars were probably esterified by the enzyme. The hydrolysis of PCW was incomplete after an incubation time of $19 \mathrm{~h}$. The protein content was highest after $19 \mathrm{~h}$ of incubation. This suggests the release of cytoplasmic proteins during the enzyme treatment and their co-precipitation with the oxidized tannins of the cell wall. We observed that the pasteurization of the crude puree before incubation brought about heat-coagulation of the cell wall cytoplasmic proteins. It is thought that in this case, as well as in the case of a long enzyme incubation time, the binding sites of enzymes on some cell wall polysaccharides were possibly masked, thus hindering the enzymatic breakdown. This could also possibly explain the inefficiency of the enzyme treatment in certain cases. These observations support the view that industrial blanching, which is used to sterilize and soften the guava fruit, is not recommended before enzyme treatment. 
Table 3. Composition $(\mathrm{g} / \mathrm{kg})$ of PCW from sieved puree and percentage hydrolysis of constituents

\begin{tabular}{|l|l|l|l|l|l|}
\hline & \multicolumn{4}{l|}{ Incubation time (h) } & \multicolumn{2}{l|}{} \\
\hline & 0 & 0.5 & 2 & 5 & 19 \\
\hline Uronic acids $^{\mathrm{a}}$ & 130 & $78(47.6)^{\mathrm{e}}$ & $72(57.1)^{\mathrm{e}}$ & $57(71.4)^{\mathrm{e}}$ & $45(77.7)^{\mathrm{e}}$ \\
\hline Protein (N x 6.25) $^{\mathrm{e}}$ & 58 & $59(11.0)^{\mathrm{e}}$ & $64(17.2)^{\mathrm{e}}$ & $67(20.6)^{\mathrm{e}}$ & $126(\mathrm{nd})^{\mathrm{f}}$ \\
\hline Methanol & 13 & $5(66.3)^{\mathrm{e}}$ & $4(76.9)^{\mathrm{e}}$ & $3(84.1)^{\mathrm{e}}$ & $2(91.1)^{\mathrm{e}}$ \\
\hline Acetic acid $^{\mathrm{f}}$ & 26 & $26(14.3)^{\mathrm{e}}$ & $25(28.6)^{\mathrm{e}}$ & $28(26.2)^{\mathrm{e}}$ & $28(30.7)^{\mathrm{e}}$ \\
\hline Rhamnose $^{\mathrm{b}}$ & 13 & $6(59.6)^{\mathrm{e}}$ & $6(65.4)^{\mathrm{e}}$ & $5(73.6)^{\mathrm{e}}$ & $3(85.0)^{\mathrm{e}}$ \\
\hline Fucose $^{\mathrm{b}}$ & 9 & $9(12.5)^{\mathrm{e}}$ & $10(16.7)^{\mathrm{e}}$ & $9(31.3)^{\mathrm{e}}$ & $6(56.7)^{\mathrm{e}}$ \\
\hline Arabinose $^{\mathrm{b}}$ & 77 & $50(43.2)^{\mathrm{e}}$ & $47(54.2)^{\mathrm{e}}$ & $32(71.4)^{\mathrm{e}}$ & $18(84.8)^{\mathrm{e}}$ \\
\hline Xylose $^{\mathrm{b}}$ & 75 & $83(3.2)^{\mathrm{e}}$ & $96(4.0)^{\mathrm{e}}$ & $113(4.0)^{\mathrm{e}}$ & $100(13.3)^{\mathrm{e}}$ \\
\hline Mannose $^{\mathrm{b}}$ & 25 & $24(16.0)^{\mathrm{e}}$ & $28(16.0)^{\mathrm{e}}$ & $25(31.3)^{\mathrm{e}}$ & $20(48.0)^{\mathrm{e}}$ \\
\hline Galactose $^{\mathrm{b}}$ & 31 & $35(1.2)^{\mathrm{e}}$ & $37(10.5)^{\mathrm{e}}$ & $34(24.6)^{\mathrm{e}}$ & $25(47.6)^{\mathrm{e}}$ \\
\hline${\text { Glucose (non-cellulosic })^{\mathrm{b}, \mathrm{c}}}^{\mathrm{e}}$ & 48 & $75(0.0)^{\mathrm{e}}$ & $73(0.0)^{\mathrm{e}}$ & $61(12.6)^{\mathrm{e}}$ & $61(12.0)^{\mathrm{e}}$ \\
\hline Glucose (cellulosic) $^{\mathrm{b}, \mathrm{d}}$ & 293 & $277(21.5)^{\mathrm{e}}$ & $341(12.7)^{\mathrm{e}}$ & $382(10.4)^{\mathrm{e}}$ & $282(37.5)^{\mathrm{e}}$ \\
\hline
\end{tabular}

${ }^{a}$ Expressed as anhydrogalacturonic acid

${ }^{\mathrm{b}}$ Maximum value obtained by Saeman or TFA hydrolysis

${ }^{\mathrm{c}}$ Obtained by TFA hydrolysis

${ }^{\mathrm{d}}$ Obtained by difference between Saeman and TFA hydrolysis

${ }^{\mathrm{e}}$ Values in parentheses are the percentage hydrolysis of each constituent

${ }^{\mathrm{f}}$ Not determined

Size exclusion chromatography results on the liquid phaseare presented in Fig. 1 after $2 \mathrm{~h}$ and 19 hincubation with Klerzyme Extra,and $19 \mathrm{~h}$ after dialysis. After $19 \mathrm{~h}$ incubation, the solubilised pectic polymers separated as follows: The high molecular mass fraction, eluting with the column void volume $\left(\mathrm{V}_{0}\right)$, was rich in neutral sugars and linked to a small proportion of galacturonic acid residues. The low molecular mass fraction, eluting with the column total volume $\left(\mathrm{V}_{\mathrm{t}}\right)$, was rich in galacturonic acid. After $2 \mathrm{~h}$ incubation, the fraction obtained for $\mathrm{V}_{0}$ contained $31.1 \%$ of the total neutral sugars and $10.9 \%$ of the total uronic acids present in the supernatant. After $19 \mathrm{~h}$ incubation, the proportions of neutral sugars and uronic acids in the $\mathrm{V}_{0}$ fraction were $45.2 \%$ and $7.0 \%$, respectively. The supernatant was enriched with neutral polymers having a high molecular mass. Structural analysis by permethylation of the high molecular mass fraction is presented in Table 4.
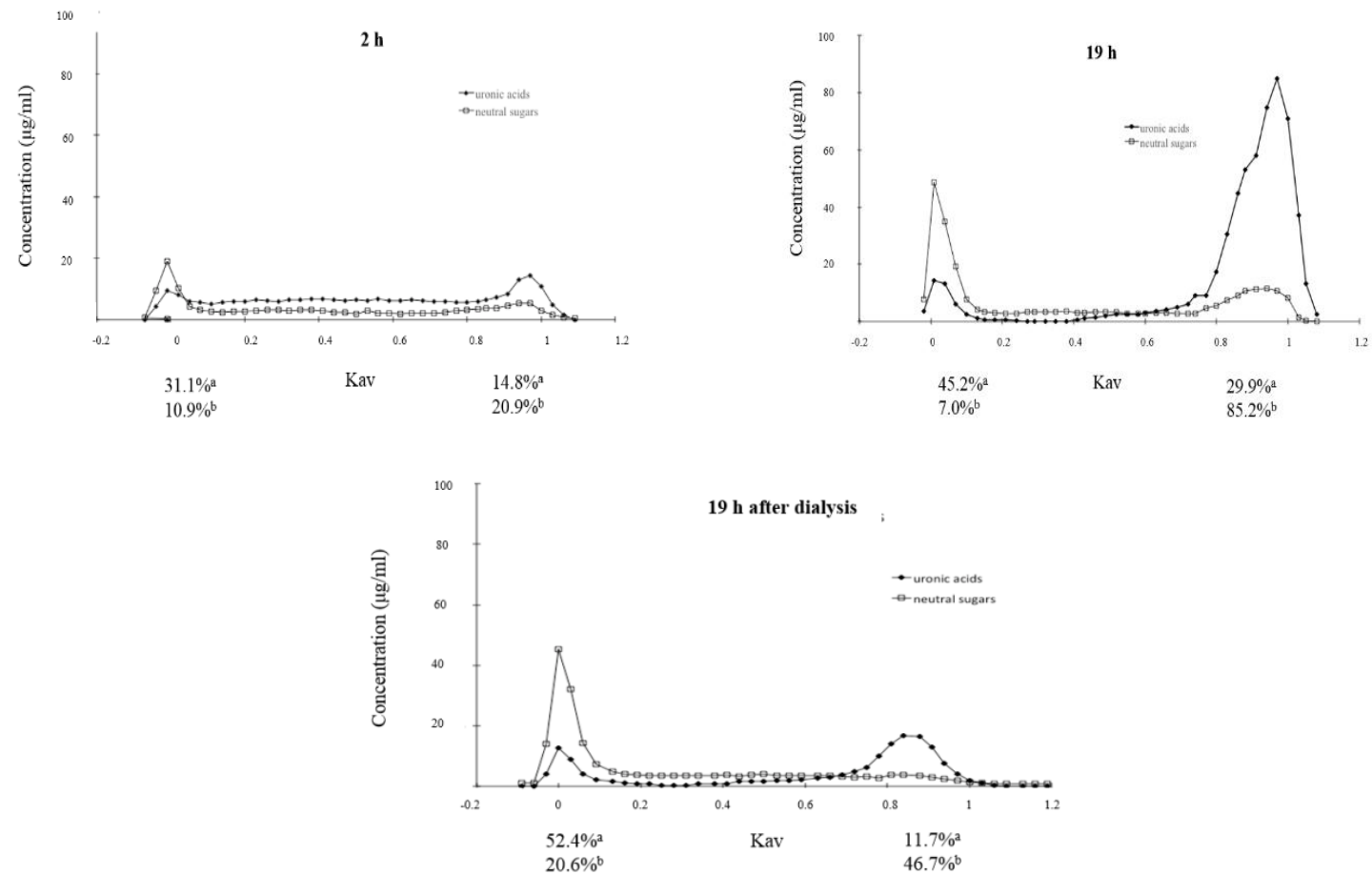

Figure 1. Size exclusion chromatography on Sephadex G100 of liquid phase from mesocarp parenchyma cell walls after enzymatic treatment with Klerzyme Extra for various incubation times: $2 \mathrm{~h} ; 19 \mathrm{~h} ; 19 \mathrm{~h}$ after dialysis. ${ }^{\mathrm{a}} \%$ of total neutral sugars

${ }^{\mathrm{b}} \%$ of total galacturonic acid 
Table 4. Methylation analysis of the high molecular mass fraction from the liquid phase of PCW broken down by Klerzyme Extra

\begin{tabular}{|c|c|}
\hline Methyl ether & Relative percentage \\
\hline 3-Me-Rha & 0.7 \\
\hline Rha & 0.8 \\
\hline $2,3,5-\mathrm{Me}_{3}-\mathrm{Ara}^{\mathrm{a}}$ & 18.0 \\
\hline 2,5-Me $-\mathrm{Me}_{2}-\mathrm{Ara}$ & 2.5 \\
\hline 3,5-Me $\mathrm{Me}_{2}$ Ara & 0.5 \\
\hline 2,3- $\mathrm{Me}_{2}-\mathrm{Ara}$ & 4.2 \\
\hline 2-Me-Ara & 2.4 \\
\hline Ara & 9.9 \\
\hline $2,3,4,6-\mathrm{Me}_{4}-\mathrm{Gal}$ & 0.9 \\
\hline $2,4,6-\mathrm{Me}_{3}$-Gal & 5.3 \\
\hline 2,3,6--Me ${ }_{3}-\mathrm{Gal}$ & 1.5 \\
\hline $2,6-\mathrm{Me}_{2}-\mathrm{Gal}$ & 3.0 \\
\hline $2,3-\mathrm{Me}_{2}-\mathrm{Gal}$ & 0.9 \\
\hline 2,4-Me $\mathrm{Me}_{2} \mathrm{Gal}$ & 11.7 \\
\hline 2-Me-Gal & 5.8 \\
\hline $2,3,4,6-\mathrm{Me}_{4}-\mathrm{Glc}$ & 7.2 \\
\hline $2,3,6-\mathrm{Me}_{3}-\mathrm{Glc}$ & 0.8 \\
\hline 2,3,4,6-Me $-\mathrm{Man}$ & 7.1 \\
\hline 3,4,6- $\mathrm{Me}_{3}-\mathrm{Man}$ & 4.6 \\
\hline 2,4,6- $\mathrm{Me}_{3}-\mathrm{Man}$ & 5.0 \\
\hline 3,4-Me $-\mathrm{Man}$ & 4.7 \\
\hline
\end{tabular}

${ }^{\mathrm{a}} \mathrm{By}$ way of example, 2,3,5-Me $\mathrm{Me}_{3}$-Ara denotes 2,3,5-tri- $O$-methyl-1,5-di- $O$-acetyl-arabinitol

Methyl ethers from arabinose and galactose predominate. They represent about $40 \%$ and about $30 \%$ of total methyl ethers, respectively. Arabinofuranose, which represents about $50 \%$ of the total arabinose, was present mainly as non-reducing terminal units. Highly substituted arabinans, possibly O-3 linked and O-2,3 linked, were detected by the occurrence of 2-linked and 2,3-linked units and non-methylated arabinose units. A small percentage of 1,3-linked arabinose units were also detected and could originate from type II arabinogalactan side chains. Moreover, galactose exhibited mainly 2-, 2,4- and 2,4,6-linked residues which represent about $79 \%$ of the total galactose. This confirms the predominance of type II arabinogalactans. Type I arabinogalactans were also detected as revealed by 2,6- and 2,3,6-linked galactose residues (about $15 \%$ of total galactose). Nearly all the glucose was in the form of terminal residues that cannot be linked to the very small proportion of 1,4-linked glucose residues. Mannose, which represents about $20 \%$ of total methyl ethers, was mainly at the non-reducing end and also in the form of 1,2-linked units. It is not possible for such polysaccharide structures to come from the cell wall, and it is thought that the mannose and glucose detected probably originated from impurities in the fungal enzyme preparation. Structural analysis by permethylation shows that the high molecular mass fraction mainly contained highly substituted arabinans and type II arabinogalactans, and a small portion of the rhamnogalacturonic backbone. This fraction represents the hairy regions of the liberated rhamnogalacturonans, which were resistant to enzymatic hydrolysis. The low molecular mass fraction contained, after $19 \mathrm{~h}$ of incubation, $29.9 \%$ of the neutral sugars and $85.2 \%$ of the hydrolyzeduronic acids. Almost all of the released acids were found in the low molecular mass fraction, which corresponds to the homogalacturonic regions (smooth regions) of the liberated pectic polymers. Pectinolytic enzymes have been shown to hydrolyze similar fractions of sycamore [27] and apple [28] cell walls. It should also be noted that the peak eluted at $\mathrm{V}_{\mathrm{t}}$ has a shoulder, indicating the presence of two incompletely separated populations with different $\mathrm{K}_{\mathrm{av}}$ values $\left(\mathrm{K}_{\mathrm{av}}=0.9\right.$ and $\mathrm{K}_{\mathrm{av}}=1$, respectively). After dialysis of the supernatant (Fig. 1), a relatively homogeneous population with a $\mathrm{K}_{\mathrm{av}}$ value of about 0.9 contained half the initial content of neutral sugars and uronic acids. The acid fraction with the lowest mass (Kav of about 1) consisted of dialyzable neutral and acidic monomers and oligomers from the homogalacturonic regions which were released by the pectinolytic enzymes.

\subsection{Hydrolysis of soluble polysaccharides (SP)}

Table 5 presents the composition of serum-soluble polysaccharides. The SP content of the serum (about 1 $\mathrm{mg} / 100 \mathrm{ml}$ ) remained comparable overall when the incubation time was increased. 
Table 5. Composition of serum-soluble polysaccharides

\begin{tabular}{|l|l|l|l|l|l|}
\hline & \multicolumn{5}{|l|}{ Incubation time $(\mathrm{h})$} \\
\hline & 0 & 0.5 & 2 & 5 & 19 \\
\hline Total soluble polysaccharides $^{\mathrm{a}}$ & 9400 & 9950 & 9500 & 12180 & 9400 \\
\hline Uronic acids $^{\mathrm{a}}$ & 5320 & 6000 & 5340 & 7211 & 5424 \\
\hline Methanol $^{\mathrm{a}}$ & $686(70.9)^{\mathrm{c}}$ & $567(52.0)$ & $608(62.6)$ & $670(51.1)$ & $310(31.4)$ \\
\hline Acetic acid $^{\mathrm{a}}$ & 103 & 129 & 124 & 195 & 179 \\
\hline Rhamnose $^{\mathrm{a}, \mathrm{b}}$ & 113 & 149 & 162 & 268 & 235 \\
\hline Fucose $^{\mathrm{a}, \mathrm{b}}$ & 9 & 20 & 19 & 24 & 19 \\
\hline Arabinose $^{\mathrm{a}, \mathrm{b}}$ & 780 & 1055 & 922 & 1425 & 1448 \\
\hline Xylose $^{\mathrm{a}, \mathrm{b}}$ & 56 & 50 & 38 & 37 & 38 \\
\hline Mannose $^{\mathrm{a}, \mathrm{b}}$ & 9 & 10 & 10 & 12 & 9 \\
\hline Galactose $^{\mathrm{a}, \mathrm{b}}$ & 207 & 269 & 181 & 244 & 254 \\
\hline Glucose $^{\mathrm{a}, \mathrm{b}}$ & 75 & 80 & 48 & 85 & 56 \\
\hline
\end{tabular}

${ }^{\mathrm{a}} \mathrm{mg} / \mathrm{L}$ of serum

bobtained by TFA hydrolysis

${ }^{c}$ values in parentheses are the degree of methylation

During hydrolysis, the soluble fraction was enriched with rhamnose, arabinose and acetic acid. This indicates simultaneous solubilisation of rhamnogalacturonans (which are highly acetylated) and arabinans. A highly acetylated rhamnogalacturonic fraction linked to arabinans has been reported by [26] in apple juice. It could therefore be assumed that the presence of acetylated galacturonic acid residues in the hairy regions of guava pectins and the swapping of the rhamnose/galacturonic acid units explain, as suggested by [26], their resistance to a harsh enzyme treatment. The importance of rhamnogalacturonan hydrolases and of rhamnogalacturonanacetylesterases is well documented [29]. Although we did not detect these enzyme activities in Klerzyme Extra, the highly acetylated residual fraction in the serum might indicate that the enzymes may not be active on these substrates.

The uronic acid and methanol content of the serum SP varied only slightly, whereas there was a strong release of these components from the cell wall. These results were consistent with a significant loss of the methylated oligogalacturonides during dialysis. Furthermore, it would be noted that the degree of methylesterification decreased greatly from $70.9 \%$ to $31.4 \%$ at $0 \mathrm{~h}$ and $19 \mathrm{~h}$ incubation, respectively. However, the fact that the proportion of galacturonic acid did not increase indicated that the dispersionof the cell wall acid fractions compensated for the loss of the dialyzableoligogalacturonides.

Figures 2A, 2B, 2C, 2D, 2E and 2F represent the results of size exclusion chromatography of soluble polysaccharides from crude puree after treatment with Klerzyme Extra for varying incubation times 0 h, 0.5 h, 2 h, $5 \mathrm{~h}, 19 \mathrm{~h}$ and $19 \mathrm{~h}$ plus dialysis, respectively.
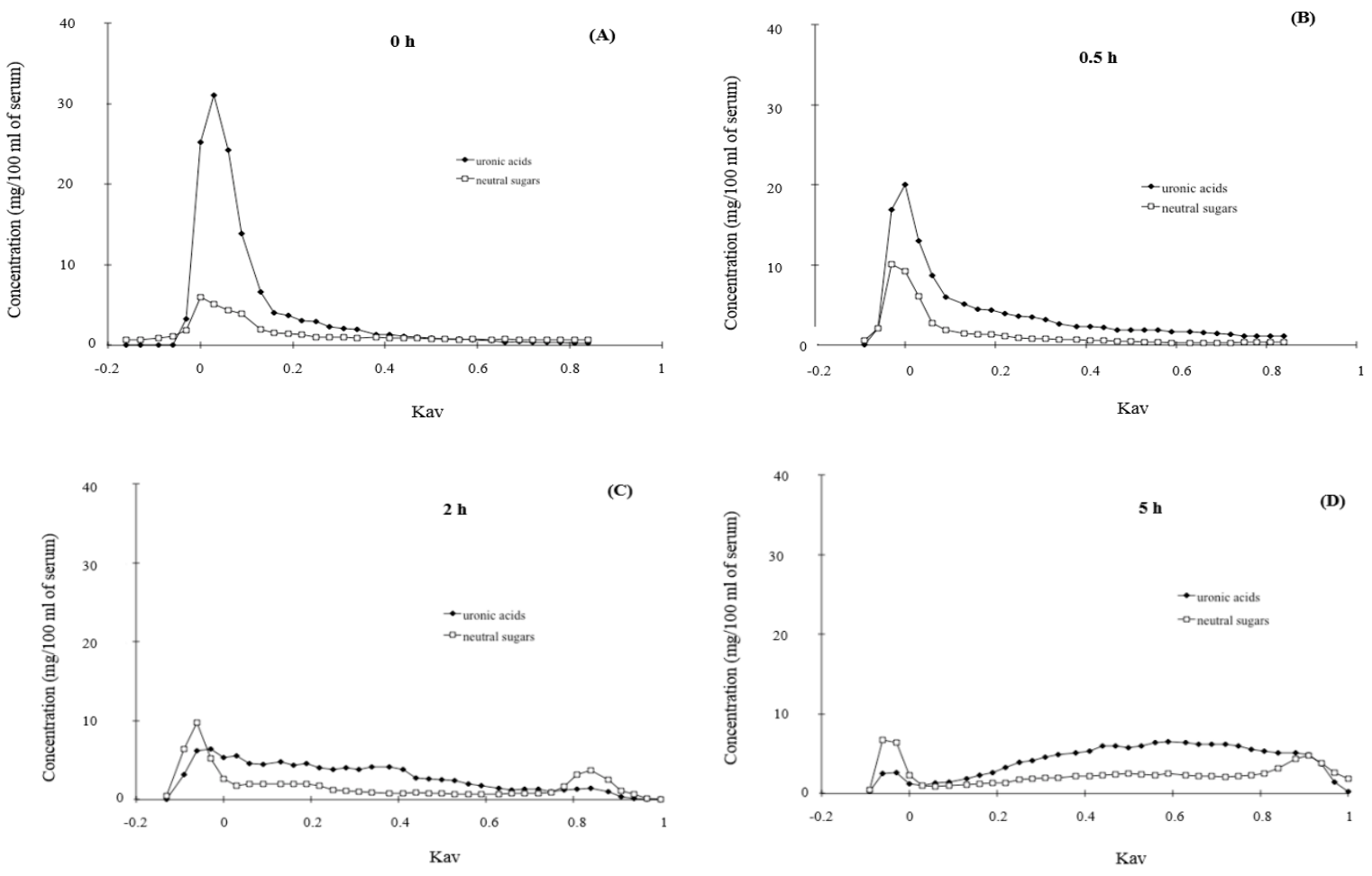

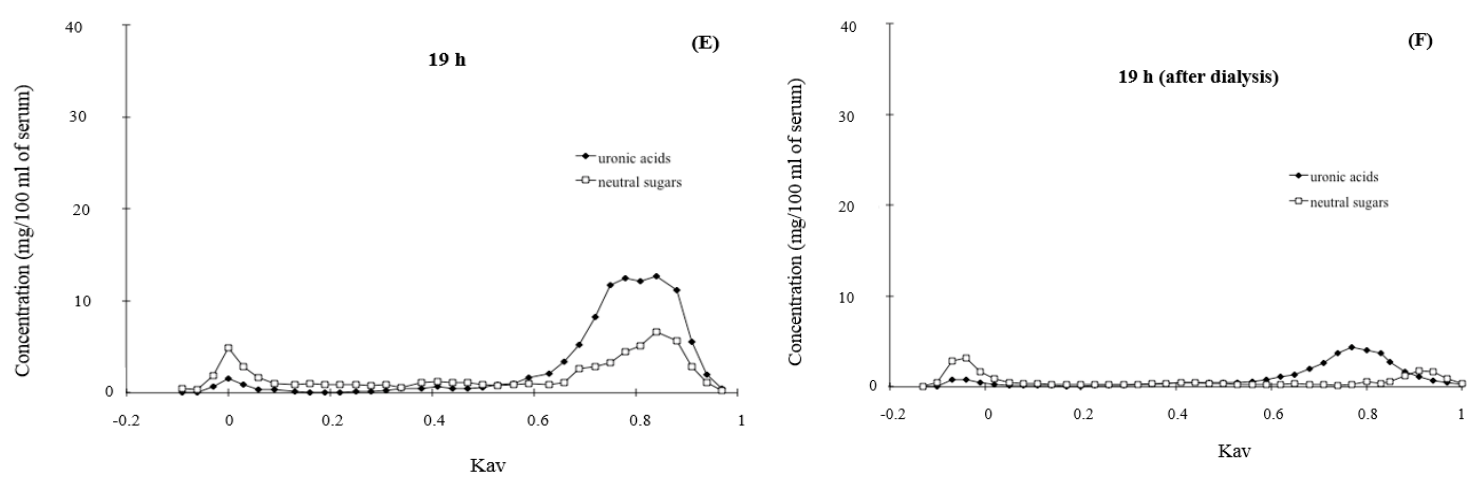

Figure 2. Size exclusion chromatography on Sephadex G100 of purified soluble polysaccharides from raw guava puree after enzymatic treatment with Klerzyme Extra for various incubation times: $(A)=0 \mathrm{~h} ;(\mathrm{B})=0.5 \mathrm{~h}$; $(\mathrm{C})=2 \mathrm{~h} ;(\mathrm{D})=5 \mathrm{~h} ;(\mathrm{E})=19 \mathrm{~h} ;(\mathrm{F})=19 \mathrm{~h}$ after dialysis.

Breakdown products of enzyme treatment were analysed for uronic acid and neutral sugar content after fractionation by size exclusion chromatography. For the control with no enzyme, the neutral sugars and uronic acids as a whole eluted at the column void volume $\left(\mathrm{V}_{0}\right)$ (Fig. 2A). By contrast, after $19 \mathrm{~h}$ incubation with Klerzyme Extra, these compounds separated into two fractions (Fig. 2E). This indicates the gradual breakdown of the high molecular mass pectic polymers. The high molecular mass fraction eluting at $\mathrm{V}_{0}$ was a neutral fraction and contained $19.4 \%$ of the total neutral sugars and $3.8 \%$ of the total uronic acids. The low molecular mass fraction from $\mathrm{K}_{\mathrm{av}}=0.6$ to $\mathrm{K}_{\mathrm{av}}=1$ consisted of $58.2 \%$ of the total neutral sugars and $90.6 \%$ the total uronic acids. The latter showed a high polydispersity, indicating the presence of fractions with varying molecular masses. After dialysis of the serum treated with Klerzyme Extra for $19 \mathrm{~h}$ (Fig. 2F), the peak for neutral sugars was centred aroundKav $=0.9$ while the peak for low molecular mass uronic acids was centred around $\mathrm{Kav}=0.8$. This would indicate that the neutral sugars and the uronic acids were not from the same polysaccharide. However, the relative proportions of the total neutral sugars and uronic acids present in the fractions decreased (loss of $32.3 \%$ and $8.2 \%$, respectively). These results show that the pectic polymers initially present in the serum were partially hydrolyzed to dialyzable oligogalacturonides.

\section{Conclusions}

We have shown that Klerzyme Extra has unique properties which make it the enzyme of choice in industrial applications. When guava puree was treated with this enzyme, two mechanisms were observed in the puree. The first mechanism occurred in the liquid phase and allowed the hydrolysis of serum polysaccharides. The second mechanism occurred in the solid phase and allowed the partial hydrolysis of the cell wall and the solubilization of certain polysaccharides. The enzyme exhibited hemicellulolytic, cellulolytic and pectinolytic activity and had a macerating action on guava puree. The medium maintained a puree consistency without phase separation while its fluidity increased. Although Klerzyme Extra is a commercial preparation with high hemicellulolytic and cellulolytic activities, the cell wall framework could not be completely broken down. This phenomenon could explain why the medium preserved a puree consistency regardless of the incubation time, whereas its fluidity increased.

\section{References}

[1]. O. Marcelin, J. Mourges and A. Talmann, Les polyosides de la goyave (Psidiumguajava L.). Evolution au cours de la croissance et incidences technologiques liées à l'obtention de purées et de jus. Fruits45, 1990, 511-520.

[2]. H. P. Sharma, H. Patel and S. Sharma, Enzymatic extraction and clarification of juice from various fruits-A review. Trends in Post Harvest Technology2, 2014, 01-14.

[3]. J. E. Breeke, H. J. P. Redelinghuys and P. A. Torline, Enzyme treatment and concentration of guava pulp. ActaHort, Fruit and Vegetable for Processing194, 1986, 229-240.

[4]. I. A. G. Weinert and P. J. Van Wik, Guava puree with reduced stone cell content: preparation and characteristics of concentrates and nectars. Int J Food SciTechnol23, 1988, 501-510.

[5]. O. Marcelin, P. Williams and J. M. Brillouet, Isolation and characterisation of two main cell wall types from guava (Psidiumguajava L.) fruit. Carbohydr Res240, 1993, 233-243.

[6]. O. Marcelin, S. Salunier and J. M. Brillouet, Extraction and characterisation of water-soluble pectic substances from guava (Psidiumguajava L.) fruit. Carbohydr Res212, 1991, 159-167.

[7]. O. Marcelin, L. Saulnier, P. Williams and J. M. Brillouet, Reexamination of composition and physic-chemical characteristics of water-soluble pectic substances from guava (Psidiumguajava L.) fruit. Carbohydr Res242, 1993, 315-321.

[8]. O. H. Lowry, N. J. Rosebrough, A. L. Farr and R. J. Randall, Protein measurement with the folin phenol reagent. J BiolChem193, 1951, 265-275.

[9]. N. A. Nelson, Photometric adaptation of the Somogyi method for the determination of glucose. J BiolChem153, 1944, 375-380.

[10]. C. Versteeg, F. M. Rombouts and W. Pilnik, Purification and some characteristics of two pectinesterase isoenzymes from orange. LWT- Food SciTechnol11, 1978, 267-274. 
[11]. A. G. J. Voragen, F. M. Rombouts and W. Pilnik, The influence of the degree of esterification on the activity of pectin- and pectatelyases. LWT- Food SciTechnol4, 1971, 126-128.

[12]. X. Rouau and E. Odier, Purification and properties of two enzymes from Dichomitussqualens which exhibit both cellobiohydrolase and xylanase activity. Carbohydr Res145, 1986, 279-292.

[13]. R. R. Selvendran, Analysis of cell wall material from plant tissues: extraction and purification. Phytochem14, 1975 , $1011-1017$.

[14]. J. A. Lomax, A. H. Gordon and A. A. Chesson, Multiple-column approach to the methylation analysis of plant cell walls. Carbohydr Res138, 1985, 177-188.

[15]. P. Albersheim, D. J. Nevins, P. D. English and A. A. Karr, Method for the analysis of sugars in plant cell-wall polysaccharides by gas-liquid chromatography. Carbohydr Res5, 1967, 340-345.

[16]. C. Hoebler, J. L. Barry, A. David and J. Delort-Laval, Rapid acid hydrolysis of plant cell wall polysaccharides and simplified quantitative determination of their neutral monosaccharides by gas-liquid chromatography. J Agric Food Chem37, 1989, 360-365

[17]. A. B. Blakeney, P. J. Harris, R. J. Henry and B. B. B. Stone, Simple and rapid preparation of alditol acetates for monosaccharide analysis. Carbohydr Res113, 1983, 291-299.

[18]. L. Saulnier, J. M. Brillouet and J. P. Joseleau, Structural studies of pectic substances from the pulp of grape berries. Carbohydr Res182, 1988, 63-78.

[19]. N. Blumenkrantz and G. Asboe-Hansen, New method for quantitative determination of uronic acids. Anal Biochem54, 1973, 484489

[20]. J. F. Thibault, Automatisation du dosage des substances pectiques par la méthode au méta-hydroxydiphényl. LWT- Food SciTechnol12, 1979, 247-251.

[21]. M. T. Tollier and J. P. Robin, Adaptation de la méthode à l'orcinol sulfurique au dosage automatique des glucides neutres totaux. Ann Technol. Agric28, 1979, 1-15.

[22]. J. A. Klavons and R. D. Bennett, Determination of methanol using alcohol oxydase and its application to methyl ester content of pectins J Agric Food Chem34, 1986, 597-599.

[23]. M. Moll, R. Flayeux and J. M. Lehuede, Détermination automatique de l'azote total dans le moût et la bière. IndAgricAlim6, 1975, 631-633.

[24]. A. G. J. Voragen, H. A. Schols, H. A. I. Siliha and W. Pilnik, Enzymic lysis of pectic substances in cell walls: some implications for fruit juice technology. ACS Symposium series: Chemistry and Function of Pectins 1985, 230-247.

[25]. S. Yusof, S. Mohamed and A. A. Bakar, Effect of fruit maturity on the quality and acceptability of guava puree. Food Chem30, 1988, 45-58.

[26]. H. A. Schols, M. A. Posthumus and A. G. J. Voragen, Structural features of hairy regions of pectins isolated from apple juice produced by the liquefaction process. Carbohydr Res206, 1990, 117-129.

[27]. K. W. Talmadge, K. Keegstra, W. D. Bauer and P. Albersheim, The structure of plant cell walls. I: the macromolecular components of the walls of suspension-cultured sycamore cells with a detailed analysis of the pectic polysaccharides. Plant Physiol51, 1973, $158-173$.

[28]. C. M. G. C. Renard, M. J. F. Searle van Leeuwen, A. G. J. Voragen, J. F. Thibault and W. Pilnik, Studies on apple protopectin. II: apple cell wall degradation by pure polysaccharidases and their combinations. CarbohydrPolym14, 1991, 295-314.

[29]. E. Bonnin, C. Garnier and M. C. Ralet, Pectin-modifying enzymes and pectin-derived materials: applications and impacts. ApplMicrobiolBiotechnol98, 2014, 519-532. 